\title{
Peningkatan Prestasi Belajar PKn melalui Metode Kooperatif Pada Siswa SD
}

\author{
Christina Suhartini \\ SD Negeri 2 Nanggulan Kecamatan Cawas Kabupaten Klaten \\ christina@yahoo.co.id
}

\begin{abstract}
The formulation of the problem in this study is whether the cooperative method can be used to improve PKn learning achievement for grade IV students of SD Negeri 2 Nanggulan, District of Cawas, Klaten Regency, second semester 2017/2018 academic year? The goal to be achieved is to prove that the cooperative method can be used to improve PKn learning achievement of grade IV students of SD Negeri 2 Nanggulan, District of Cawas, Klaten Regency, second semester of the school year 2017/2018. This research was conducted at Nanggulan Cawas Klaten Public Elementary School 2. While the time of the study was conducted from February to March 2018. The subjects of this study were grade IV students of SD Negeri 2 Nanggulan Cawas Klaten in the second semester of the school year 2017/2018. This action research uses the classroom action research flow. The data analysis technique used uses several stages, namely data reduction, presentation and conclusion. From the results of the research carried out since planning, repairs to implementation and evaluation, it can be concluded that the cooperative method can be used to improve PKn learning achievement of fourth grade students of SDN 2 Nanggulan, District of Cawas, Klaten Regency, second semester 2017/2018 school year. This was proven before the improvement in the percentage of students' completeness in learning was only $27.78 \%$ or 5 students, in the improvement of the first cycle to $55.6 \%$ (of 18 students, which was not completed 8 students) and in the second cycle the percentage of student mastery reached $94,44 \%$. Of the 18 students, 17 of them have achieved mastery learning, while the one student is still incomplete.
\end{abstract}

\begin{abstract}
Abstrak: Rumusan masalah pada penelitian ini adalah Apakah metode kooperatif dapat digunakan untuk meningkatkan prestasi belajar PKn siswa kelas IV SD Negeri 2 Nanggulan Kecamatan Cawas Kabupaten Klaten semester II tahun pelajaran 2017/2018? Adapun tujuan yang ingin dicapai adalah untuk membuktikan bahwa metode kooperatif dapat digunakan untuk meningkatan prestasi belajar PKn siswa kelas IV SD Negeri 2 Nanggulan Kecamatan Cawas Kabupaten Klaten semester II tahun pelajaran 2017/2018. Penelitian ini dilakukan SD Negeri 2 Nanggulan Cawas Klaten. Sedangkan waktu penelitian dilaksanakan pada bulan Februari sampai dengan Maret 2018. Subjek penelitian ini adalah siswa kelas IV SD Negeri 2 Nanggulan Cawas Klaten semester II tahun pelajaran 2017/2018. Penelitian tindakan ini menggunakan alur penelitian tindakan kelas. Teknik analisis data yang digunakan menggunakan beberapa tahapan yaitu reduksi data, sajian dan penarikan kesimpulan. Dari hasil penelitian yang dilaksanakan sejak perencanaan, perbaikan sampai pelaksanaan dan evaluasi, dapat diambil kesimpulan bahwa metode kooperatif dapat digunakan untuk meningkatkan prestasi belajar PKn siswa kelas IV SD Negeri 2 Nanggulan Kecamatan Cawas Kabupaten Klaten semester II tahun pelajaran 2017/2018. Hal ini terbukti sebelum perbaikan persentase ketuntasan siswa dalam belajar hanya $27,78 \%$ atau 5 siswa, pada perbaikan siklus I menjadi $55,6 \%$ (dari 18 siswa, yang belum tuntas 8 siswa) dan pada siklus II persentase ketuntasan belajar siswa mencapai 94,44\%. Dari 18 siswa, 17 siswa di antaranya sudah mencapai ketuntasan belajar, sedangkan yang 1 siswa masih belum tuntas.
\end{abstract}

Kata Kunci: prestasi belajar, metode kooperatif. 


\section{Pendahuluan}

Sistem pendidikan Nasional mengacu pada Undang-Undang No: 20 Tahun 2003 menyatakan bahwa pendidikan adalah usaha sadar dan terancam untuk mewujudkan suasana belajar dan proses pembelajaran agar peserta didik secara aktif mengembangkan potensi dirinya [1]. Untuk memiliki kekuatan spiritual keagamaan, pengendalian diri, kepribadian, kecerdasan akhlak mulia, serta keterampilan yang diperlukan dirinya, masyarakat, bangsa dan Negara.

Dari uraian di atas menunjukkan bahwa pemerintah menitik beratkan pembangunan pendidikan pada peningkatan mutu setiap jenjang pendidikan, dalam usaha menyiapkan generasi muda yang terampil, berbudi pekerti luhur, cinta tanah air. Mata pelajaran pendidikan pancasila dan kewarganegaraan mempunyai peranan yang sangat strategis, untuk melaksanakan pendidikan Pancasila perlu dipahami, dihayati dan diamalkan, dengan memahami Pancasila dapat membentuk moral bangsa yang terwujud dalam perilaku kehidupan sehari-hari. Salah satu faktor penting bagi kemajuan suatu bangsa adalah pendidikan. Melalui pendidikan bangsa ini membebaskan masyarakat dari kebodohan dan keterpurukan serta dapat mengembangkan sumber daya manusia yang percaya diri untuk bersaing dan bersanding dengan bangsa lain. Salah satu faktor yang penting untuk mencapai tujuan pendidikan adalah proses belajar mengajar yang dilaksanakan. Keberhasilan proses belajar mengajar tidak bisa lepas dari faktor pendidik, peserta didik, sarana prasarana, materi dan metode.

Proses belajar mengajar merupakan kegiatan interaksi antara guru-peserta didik dan komunikasi timbal balik yang berlangsung dalam situasi edukatif untuk mencapai tujuan belajar. Interaksi dan komunikasi timbal balik antara guru dan peserta didik merupakan ciri dan syarat utama berlangsungnya proses belajar mengajar. Belajar bukan hanya menghafal dan bukan hanya pula mengingat. Akan tetapi, belajar adalah suatu proses yang ditandai adanya perubahan segala hasil proses belajar yang dapat ditunjukkan dengan berbagai bentuk, seperti berubah pengetahuannya, pemahamannya, sikap dan tingkah lakunya, keterampilannya, kecakapan dan kemampuan, daya reaksi, daya penerimaan, dan aspek-aspek lain yang ada pada individu.

Prestasi belajar adalah hasil yang dicapai dalam mengikuti suatu pelajaran yang menunjukkan taraf kemampuan siswa dalam mengikuti program belajar dalam waktu tertentu [2]. Kemampuan siswa mengikuti program belajar dapat diukur secara langsung dengan tes. Hanya dengan keuletan dan optimisme diri anak dapat mencapainya. Dari hasil prestasi belajar ini dapat diketahui apakah siswa sudah menguasai suatu materi atakah belum. Prestasi belajar adalah hasil suatu kegiatan belajar yang telah dikerjakan, diciptakan, baik secara individual maupun secara kelompok. Prestasi belajar tidak pernah dihasilkan selama seseorang tidak melakukan kegiatan belajar. Dalam kenyataan untuk mendapatkan prestasi belajar yang baik tidak semudah yang dibayangkan, perlu diperjuangkan dan dihadapi berbagai tantangan untuk mencapainya. Hanya dengan keuletan dan optimisme dirilah anak dapat mencapainya.

Oleh karena itu wajarlah bila pencapaian prestasi belajar itu harus dengan keuletan belajar [3]. Banyak kegiatan yang biasa dijadikan sama untuk mendapatkan prestasi semuanya, tergantung dari taraf kemampuan minat masing-masing individu. Kegiatan yang mana yang akan digeluti untuk mendapatkan prestasi tersebut. Konsekuensinya kegiatan itu harus dilakukan secara optimal agar menjadi bagian pribadi.

"Prestasi belajar penelitian pendidikan tentang perkembangan dan kemajuan siswa yang berkenaan dengan penguasaan bahan pelajaran yang disajikan kepada mereka serta nilai-nilai yang terdapat dari kurikulum" [4]. Dalam proses belajar mengajar anak merupakan masalah yang utama dan pertama karena anak didiklah yang diharapkan data menyerahkan seluruh materi pelajaran yang telah diprogramkan dalam kurikulum. Dalam usaha meningkatkan mutu pendidikan, keberhasilan pencapaian target kurikulum tidak terlepas dari kemampuan guru sebagai ujung tombak dalam mentransferkan pengetahuan, disamping guru sebagai motivator, dinamisator kurikulum, dan penyampaian bahan ajaran yang dilaksanakan sesuai dengan tingkat dan perkembangan intelektual dan juga meliputi aspek-aspek keterampilan, sosial, sikap dan apresiasi terhadap siswa.

Dalam penjelasan Pasal 37 ayat 1 Undang-undang RI No. 20 tahun 2003 tentang Sistem Pendidikan Nasional disebutkan bahwa:Pendidikan agama dimaksudkan untuk membentuk peserta 
didik menjadi manusia yang beriman dan bertaqwa kepada Tuhan Yang Maha Esa serta berakhlak mulia. Pendidikan kewarganegaraan dimaksudkan untuk membentuk peserta didik menjadi manusia yang memiliki rasa kebangsaan dan cinta tanah air. Dan juga visi dan misi pendidikan nasional bertujuan untuk membentuk manusia yang beriman dan bertaqwa kepada Tuhan Yang Maha Esa, berakhlak mulia, sehat, berilmu, cakap, kreatif, mandiri serta menjadi warga negara yang demokratis dan bertanggung jawab dalam rangka mencerdaskan kehidupan bangsa.

Pancasila sebagai dasar Negara Republik Indonesia ditetapkan sebagai Dasar Negera maka nilai-nilai kehidupan bernegara dan berpemerintahan sejak saat itu hanyalah berdasarkan pada Pancasila. Ini berarti semua nilai dari kelima sila tersebut telah dipraktekkan dalam kehidupan rakyat Indonesia seperti tercantum dalam Pembukaan UUD 1945 alinea 4 adalah :

1. Ketuhanan Yang Maha Esa

2. Kemanusiaan yang adil dan beradab

3. Persatuan Indonesia

4. Kerakyatan yang dipimpin oleh hikmat kebijaksanaan dalam permusyawaratan/perwakilan.

5. Keadilan sosial bagi seluruh rakyat Indonesia

Kelima sila tersebut sebagai satu kesatuan nilai kehidupan masyarakat Indonesia (Suwito, 1983: 12). Dasar tersebut adalah kuat, kokoh karena digali dan dirumuskan dari nilai kehidupan rakyat Indonesia yang merupakan kepribadian dan pandangan hidup bangsa kita, Pancasila disepakati secara nasional, maka Pancasila merupakan suatu perjanjian seluruh rakyat Indonesia. Dari sejarah ketatanegaraan kita terbukti bahwa Pancasila mampu mempersatukan bangsa kita yang majemuk.

Pendidikan Pancasila adalah pendidikan nasional yang bertujuan membentuk sikap positif manusia sesuai dengan nilai-nilai yang terkandung dalam Pancasila. Karena di dalam diri Pancasila terkandung nilai-nilai yang berasal dari dirinya sendiri, maka nilai-nilai tersebut selalu memancar keluar [5]. Pendidikan kewarganegaraan merupakan usaha membekali peserta didik dengan pengetahuan dan kemampuan dasar yang berkenan membentuk watak, kepribadian yang berorientasi pada akhlak dan moral. Agar menjadi warga negara yang dapat diandalkan oleh bangsa dan negara. Berdasarkan pengalaman dan pengamatan, siswa kelas IV SD Negeri 2 Nanggulan, Cawas, Klaten kurang menyukai pelajaran PKn. Mereka beranggapan pelajaran PKn tidak menarik dan membosankan, guru selalu berusaha untuk menjelaskan kepada siswa tentang materi pelajaran PKn. Namun anak-anak terlihat pasif dalam belajar, mereka lebih senang bercerita denga temannya, bahkan tidak mau bertanya pada guru meskipun sebenarnya belum mengerti materi yang disampaikan guru, selain itu metode yang digunakan oleh guru adalah metode konvensional. Oleh karena itu hasil belajar PKn belum memuaskan .

Hal inilah yang mendorong dicobanya metode pembelajaran kooperatif (Cooperative Learning) yaitu metode dengan pedekatan pembelajaran yang menggunakan kelompok kecil siswa untuk bekerja sama dalam rangka memaksimalkan kondisi belajar untuk mecapai tujuan belajar. Dengan demikian diharapkan dapat mengikutsertakan siswa secara langsung terlihat atau mengalami proses belajar dan guru tidak semata-mata mendominasi kelas. Pembelajaran kooperatif adalah pembelajaran yang secara sadar dan sengaja mengembangkan interaksi yang saling asuh antar siswa untuk menghindari ketersinggungan dan kesalahpahaman yang dapat menimbulkan permusuhan [5].

Pembelajaran kooperatif merujuk pada berbagai macam metode pengajaran dimana para siswa bekerja dalam kelompok-kelompok kecil untuk saling membantu satu sama lainnya dalam memepelajari materi pelajaran. Dalam kelas kooperatif, para siswa diharapkan dapat saling membantu, saling mendiskusikan dan berargumentasi, untuk masalah pengetahuan yang mereka kuasai saat itu dan menutup kesenjangan dalam pemahaman masing-masing. Pembelajaran koopertif bukanlah gagasan baru dalam dunia pendidikan, tetapi sebelum masa belakangan ini metode ini hanya digunakan oleh beberapa guru untuk tujuan-tujuan tertentu, seperti tugas-tugas atau laporan kelompok tertentu [6].

Ada banyak alasan yang membuat pembelajaran kooperatif memasuki jalur utama praktik pendidikann kooperat. Salah satunya adalah berdasarkan penelitian dasar yang mendukung penggunaan pembelajaran kooperatif untuk meningkatkan pencapaian prestasi para siswa, dan juga 
akibat-akibat positif lainnya yang dapat mengembangkan hubungan antar kelompok, penerimaan terhadap teman sekelas yang lemah dalam bidang akademik, dan meningkatkan rasa harga diri.

Inilah inti dari pembelajaran kooperatif [6]. Dalam metode pembelajaran kooperatif, para siswa akan duduk bersama dalam kelompok yang beranggotakan empat orang untuk menguasai materi yang disampaikan oleh guru. Anggota timnya heterogen yang terdiri dari siswa yang berprestasi tinggi, sedang, dan rendah, laki-laki dan perempuan, dan berasal dari latar belakang etnik yang berbeda. Metode pembelajaran kooperatif tentu saja bukan hal baru. Para guru sudah menggunakannya selama bertahun-tahun dalam bentuk laboratorium, kelompok tugas, kelompok diskusi, dan sebagainya. Namun penelitian terakhir di Amerika dan beberapa negara lain telah menciptakan metode-metode pembelajaran kooperatif yang sistematik dan praktis yang ditujukan untuk digunakan sebagai elemen utama dalam pola pengaturan di kelas, pengaruh penerapan metode-metode ini juga telah di dokumentasikan, dan telah di aplikasikan ada kurikulum pengajaran yang lebih luas. Metode-metode ini sekarang telah digunakan secara ekstensif dalam setiap subjek yang dapat dikonsepkan, pada tingkat kelas mulai dari taman kanak-kanak sampai perguruan tinggi, dan pada berbagai macam sekolah di seluruh dunia [6]. Menurut Johnson \& Johnson cooperative learning adalah mengelompokkan siswa di dalam kelas ke dalam suatu kelompok kecil agar siswa dapat bekerja sama dengan kemampuan maksimal yang mereka miliki dan mempelajari satu sama lain dalam kelompok tersebut [7]. Sedangkan menurut Djahiri K menyebutkan cooperative learning sebagai pembelajaran kelompok kooperatif yang menuntut diterapkan pendekatan belajar yang siswa sentries, humanistik, dan demokratis yang disesuaikan dengan kemampuan siswa dan lingkungan belajar [7].

Pembelajaran kooperatif adalah pembelajaran yang secara sadar menciptakan interaksi yang silih asah, sehingga sumber belajar bagi siswa bukan hanya guru dan buku ajar, tetapi juga sesama siswa [8]. Sedangkan Abdurrahman dan Bintoro mengatakan bahwa pembelajaran kooperatif adalah pembelajaran yang secara sadar dan sistematis mengembangkan interaksi yang silih asah, silih asih, dan silih asuh antar sesama siswa sebagai latihan hidup di dalam masyarakat nyata [8]. Dari beberapa pengertian di atas peneliti dapat menyimpulkan bahwa pembelajaran kooperatif adalah suatu model pembelajran dimana siswa belajar bekerjasama dalam kelompok-kelompok kecil secara kolaboratif yang anggotanya terdiri dari 4-6 orang dengan struktur kelompok yang hiterogen dan memiliki kemampuan yang berbeda-beda, sehingga siswa dapat memanfaatkan teman sejawat (siswa lain) sebagai sumber belajar, dan dapat merangsang siswa lebih bergairah dalam belajar, dan dalam sistem ini guru sebagai fasilitator. Selain itu pembelajaran kooperatif adalah pembelajaran yang secara sadar dan sistematis mengembangkan interaksi yang silih asah, silih asih, dan silih asuh antar sesama siswa sebagai latihan hidup di dalam masyarakat nyata. Trianto mengemukakan ciri-ciri pembelajaran kooperatif diantaranya adalah sebagai berikut [9]:

a. Siswa bekerja dalam kelompok secara kooperatif untuk menuntaskan materi belajarnya.

b. Kelompok di bentuk dari siswa yang memiliki kemampuan tinggi, sedang dan rendah.

c. Bila mana mungkin, anggota kelompok berasal dari ras, budaya, suku, jenis kelamin yang berbeda-beda.

d. Penghargaan lebih berorientasi kelompok ketimbang individu

Model pembelajaran kooperatif memberikan suatu kemungkinan guru-siswa dan siswa-siswa berinteraksi dalam situasi yang kondusif, strategi ini dapat mendorong pembelajar memanfaatkan informasi, pengalaman, pemikiran, atau gagasan yang dimilikinya untuk memecahkan persoalan baru yang dihadapinya. Strategi pembelajaran kooperarif memberikan tawaran yang positif bagi penyelesaian persoalan yang dihadapi dalam proses pembelajaran di kelas. Dengan strategi pembelajaran ini diharapkan hubungan siswa-siswa akan lebih akrab, kegiatan belajar siswa di dalam kelas akan lebih bervariasi, dan yang lebih penting pengetahuan, pengalaman dan kreativitas siswa dapat dimanfaatkan seluas-luasnya untuk menyelesaikan tugas-tugas pembelajaran, baik di dalam maupun di luar kelas.

Adapun rumusan masalah dari penelitian ini adalah: Apakah metode kooperatif dapat digunakan untuk meningkatkan prestasi belajar PKn siswa kelas IV SD Negeri 2 Nanggulan Kecamatan Cawas Kabupaten Klaten semester II tahun pelajaran 2017/2018?. Tujuan penelitian ini adalah untuk membuktikan bahwa metode kooperatif dapat digunakan untuk meningkatan prestasi 
belajar PKn siswa kelas IV SD Negeri 2 Nanggulan Kecamatan Cawas Kabupaten Klaten semester II tahun pelajaran 2017/2018..

\section{Metode Penelitian}

Penelitian ini dilaksanakan di SD Negeri 2 Nanggulan Cawas Klaten dengan subyek penelitian adalah seluruh siswa kelas IV semester II tahun pelajaran 2017/2018. Penelitian dilaksanakan pada bulan Februari sampai dengan Maret 2018 dengan menyesuaikan jam pelajaran PKn kelas tersebut. Penelitian ini menggunakan pendekatan kuantitatif dan jenis penelitian yang digunakan adalah penelitian tindakan kelas (classroom action research), yaitu suatu pencermatan terhadap kegiatan belajar berupa sebuah tindakan, yang sengaja dimunculkan dan terjadi dalam sebuah kelas secara bersama [10].

Adapun dalam penelitian ini dilaksanakan dalam 4 tahap sebagai berikut: 1)Perencanaan, Guru yang berperan sebagai peneliti dan mengajar memberi penjelasan kepada siswa tentang pelaksanaan proses belajar mengajar pada mata pelajaran PKn dengan menggunakan metode kooperatif, 2) Pelaksanaan, Peneliti membagi siswa kelas IV SD Negeri 2 Nanggulan Cawas menjadi suatu kelompok-kelompok kecil, setiap kelompok terdiri dari 2 siswa, kemudian diberi tugas, 3) Observasi, Peneliti melakukan pengamatan terhadap siswa, bagaimana siswa dapat menerima pelajaran PKn dengan baik dan memperoleh nilai yang baik pula, 4) Refleksi, Peneliti mengaji ulang catatan hasil dari pengamatan dengan melihat kelebihan dan kekurangannya.

Demikian penelitian ini dilakukan sampai tahap-tahap selanjutnya sampai menunjukkan hasil yang optimal dalam pembelajaran PKn kelas IV SD Negeri 2 Nanggulan Cawas Klaten semester II tahun pelajaran 2017/2018 dengan menggunakan metode kooperatif. Teknik pengumpulan data menggunakan metode observasi, catatan lapangan, tes dan dokumentasi. Untuk mengadakan analisis data secara keseluruhan, maka dipergunakan langkah-langkah sebagai berikut:1) Reduksi Data, Reduksi data adalah pencatatan data-data diuraikan terperinci, dirangkum, dipilih, difokuskan hal-hal yang perlu sesuai dengan rumusan masalah penelitian, 2) Sajian Data,Setelah melakukan reduksi data selanjutnya dilakukan sajian/penayangan data yaitu suatu rakitan organisasi informasi yang memungkinkan penataan data. Penayangan data dilakukan dengan membuat tabulasi data sebelum dan sesudah dilakukan tindakan, 3) Kesimpulan/Verifikasi Data, Dengan membandingkan data sebelum dan sesudah tindakan akan diperoleh laporan perkembangan tentang peningkatan hasil belajar siswa pada laporan perkembangan tentang hasil belajar PKn dengan metode kooperatif.

Dalam penelitian ini indikator keberhasilan belajar yang dijadikan ukuran peningkatan keberhasilan belajar PKn dengan metode kooperatif adalah siswa yang memperoleh nilai KKM (Kriteria Ketuntasan Minimal) $\geq 70$ mencapai $80 \%$.

\section{Hasil dan Pembahasan}

1. Sebelum Perbaikan Pembelajaran

Sebelum perbaikan pembelajaran dari 18 siswa yang mencapai KKM 70 dalam pembelajaran PKn ada 5 siswa atau hanya 27,78\% yang memenuhi kriteria ketuntasan minimal dan 13 siswa atau $72,22 \%$ belum tuntas dalam pembelajaran PKn. Hal ini menunjukkan kekurang berhasilan dalam pembelajaran. Setelah peneliti merefleksi ternyata kegagalan itu disebabkan karena a) selama kegiatan belajar mengajar berlangsung siswa ramai sendiri, b) siswa belum mampu menguasai materi pelajaran yang dipelajari di kelas, c) kurang maksimalnya guru dalam menggunakan metode pembelajaran.

2. Perbaikan Pembelajaran Siklus I

Pada perbaikan pembelajaran siklus I menggunakan pembelajaran kooperatif hasil evaluasi yang diperoleh dari 18 siswa ada 10 atau 55,56\% siswa yang tuntas belajar dalam pembelajaran PKn sedangkan 8 siswa belum tuntas belajar. Peneliti merefleksikan sebab kegagalan dalam perbaikan pembelajaran siklus I, yaitu masih banyak siswa yang kurang paham dengan materi yang diajarkan guru. 
Pada siklus I ini pelaksanaannya sudah cukup baik daripada sebelum perbaikan. Hal ini terlihat dari hasil pengamatan dan rata-rata nilai yang diperoleh saat mengikuti tes. Selama mengikuti proses belajar mengajar siswa menunjukkan antusias belajar yang tinggi, suasana belajar mengajar menjadi menyenangkan, dan di antara siswa terjalin kekompakan dan kerjasama yang cukup baik. Proses belajar-mengajar masih banyak diarahkan oleh guru, namun pembelajaran cenderung terpusat pada siswa dan bukan pada guru, karena guru hanya menjadi fasilisator dan motivator. Dibandingkan dengan nilai pada pra siklus, nilai hasil belajar siswa pada siklus I cenderung lebih baik. Hal ini dikarenakan pada siklus I siswa dalam mengerjakan soal terbantu dengan diskusi yang dilakukan dengan teman kelompoknya masing-masing. Sebelum perbaikan ketuntasan siswa $27,78 \%$ dan pada perbaikan siklus I menjadi $55,56 \%$, tetapi dalam siklus I ini belum memenuhi indikator keberhasilan yaitu dari 18 siswa, yang belum tuntas masih 8 siswa.

3. Perbaikan Pembelajaran Siklus II

Pada perbaikan pembelajaran siklus II menggunakan pembelajaran kooperatif. Dalam pembelajaran kooperatif melibatkan seluruh siswa untuk terlibat langsung dalam pembelajaran, sehingga materi pelajaran akan lebih tahan lama. Dengan metode kooperatif, suasana pembelajaran pada siklus II tetap menyenangkan, siswa tetap menunjukkan antusiasmenya dalam mengikuti proses pembelajaran. Siswa terlihat aktif dalam kegiatan belajar, aktif bertanya jawab pada guru dan aktif mengerjakan tugas yang diberikan oleh guru. Proses belajar mengajar terpusat pada siswa dan guru hanya menjadi fasilitator dan motivator. Dibanding dengan nilai pada siklus I, nilai hasil belajar pada siklus II cenderung lebih baik. Penelitian menunjukkan hasil pada perbaikan pembelajaran siklus II dari 18 siswa, 17 siswa tuntas dalam pembelajaran PKn melalui metode kooperatif atau 94,44\% persentase ketuntasan belajarnya. Dari 18 siswa, hanya ada 1 siswa masih belum tuntas. Berdasarkan pada pengamatan siklus I dan siklus II, ketuntasan belajar dan tingkat ketercapaiannya setiap siklus cenderung meningkat. Maka peneliti tidak melakukan perbaikan pembelajaran siklus II karena pembelajaran PKn siswa kelas IV SD Negeri 2 Nanggulan Cawas Klaten sudah menunjukkan hasil yang cukup baik. Dengan demikian, dapat disimpulkan bahwa metode kooperatif dapat digunakan untuk meningkatkan prestasi belajar PKn siswa kelas IV SD Negeri 2 Nanggulan Kecamatan Cawas Kabupaten Klaten semester II tahun pelajaran 2017/2018.

\section{Kesimpulan}

Dari hasil penelitian yang dilaksanakan sejak perencanaan, perbaikan sampai pelaksanaan dan evaluasi, dapat diambil kesimpulan bahwa metode kooperatif dapat digunakan untuk meningkatkan prestasi belajar PKn siswa kelas IV SD Negeri 2 Nanggulan Kecamatan Cawas Kabupaten Klaten semester II tahun pelajaran 2017/2018. Hal ini terbukti sebelum perbaikan persentase ketuntasan siswa dalam belajar hanya $27,78 \%$ atau 5 siswa, pada perbaikan siklus I menjadi 55,6\% (dari 18 siswa, yang belum tuntas 8 siswa) dan pada siklus II persentase ketuntasan belajar siswa mencapai $94,44 \%$. Dari 18 siswa, 17 siswa di antaranya sudah mencapai ketuntasan belajar, sedangkan yang 1 siswa masih belum tuntas.

\section{Referensi}

[1] Undang-Undang RI No. 20 Tahun 2003. Tentang Sisdiknas. Bandung: Citra Umbara. 2006.

[2] Mufti, Ali. 1989. Penelitian Hasil Belajar. Surabaya: Usaha nasional.

[3] Djamarah, Syaiful Bahri. 1994. Prestasi Belajar dan Kompentensi Guru. Surabaya: Usaha Nasional.

[4] Harahap, Nasrun. 1994. Penelitian Hasil Belajar. Surabaya : Usaha Nasional

[5] Kunandar. 2007. Guru Profesional. Jakarta: PT Raja Grafindo Persada

[6] Slavin, Robert E. 2008. Cooperatif Learning. Bandung: Penerbit Nusa Media..

[7] Isjoni. 2007. Cooperative Learning. Bandung: Alfa Beta

[8] Wena, Made. 2009. Strategi Pembelajaran Inovatif Kontemporer Suatu Tinjauan Operasional. Jakarta: Bumi Aksara.

[9] Trianto. 2007. Model Pembelajaran Inovatif Berorientasi Kontruksivistik. Jakarta: Perstasi Pustaka.

[10] Arikunto, Suharsimi. 2001. Dasar-Dasar Evaluasi Pendidikan. Jakarta: Bina Aksara 